Article

\title{
Art as Authentic Life- Deleuze after Kierkegaard
}

\section{Arjen Kleinherenbrink}

\begin{abstract}
There is an underappreciated existentialist side to Deleuze's philosophy, which frequently addresses the question of the best mode of existence, and consistently does so in explicit dialogue with Kierkegaard. Where Kierkegaard conceptualizes the possibility of authenticity in terms of the knight of faith, Deleuze arrives at a more impersonal notion of authenticity as an act which results in a work of art purged from subjective connotations.
\end{abstract}

Keywords: Life, art, authenticity, ethics

\section{Introduction}

$\int[$ n the Fall of 1945, Gilles Deleuze and Michel Tournier attended Sartre's famous speech "Existentialism is a Humanism." The two friends were horrified by Sartre's defense of human freedom and responsibility in terms reminiscent of $18^{\text {th }}$ century Enlightenment thought: "we were floored. So our master had had to dig through the trash to unearth this worn-out mixture reeking of sweat and of the inner life of humanism." 1 This momentary shock eventually transformed into permanent disappointment: even though he kept crediting Sartre as an inspiration, the only works Deleuze ever repudiated were precisely a number of Sartrean articles written in the 1940s.

These anecdotes are well known among Deleuze scholars, which may explain why Deleuze's relation to existentialism remains underappreciated. ${ }^{2}$ A handful of texts analyze his relation to Sartre, but not a single one explores Deleuze's connection to that other famous existentialist: the Danish philosopher Søren Kierkegaard. This is surprising because Deleuze makes

${ }^{1}$ François Dosse, Gilles Deleuze and Félix Guattari - Intersecting lives (New York: Columbia University Press, 2010), 95.

2 Several exceptions exploring the Sartre-Deleuze connection include Boundas (1993), Khalfa (2000), and Somers-Hall (2006).

(c) 2014 Arjen Kleinherenbrink

http://www.kritike.org/journal/issue 15/kleinherenbrink december2014.pdf

ISSN 1908-7330

$(\mathrm{cc}) \mathrm{BY}$-NC 
frequent use of Kierkegaard's thought in ways that go far beyond casual referencing. ${ }^{3}$ From Difference and Repetition to A Thousand Plateaus and beyond, Deleuze consistently works with and through Kierkegaard whenever he arrives at questions of the good life or of the best mode of existence.

I aim to trace this relation to Kierkegaard for two reasons. ${ }^{4}$ First, Deleuze's ethics are generally held to be a blend between Stoic disengagement, Spinozist beatitude, and Nietzschean affirmation. ${ }^{5}$ Though this is not incorrect, it is certainly incomplete. The recipe needs to be supplemented with a fourth, existentialist ingredient that concerns the criteria for the result of our actions, in addition to our attitude towards them. ${ }^{6}$ Second, this explication will clarify Deleuze's frequent yet ever vague insistence that art is simultaneously at the heart of life and of ethics.

\section{The problem of "a" life}

In the essay Immanence: A Life, Deleuze repeatedly insists that life is best lived as $a$ life, emphasizing the fourth person singular. ${ }^{7}$ Though this late essay emphasizes the notion of $a$ life with unprecedented force, it was already introduced in The Logic of Sense, becoming increasingly explicit in and after the publication of $A$ Thousand Plateaus. ${ }^{8}$ Yet what does it mean? How to do it? Moreover, why do it? Deleuze is not particularly forthcoming in answering such questions, since his explanation consists in introducing a swirl of unfamiliar neologisms, including "affect," "asignifying sign," "becomingimperceptible," "the restoration of immanence," and "infinite speed." Yet this

${ }^{3}$ In his magnum opus Difference and Repetition, Deleuze explicitly states that his conceptualization of repetition amounts to "following Kierkegaard's wish to carry out the reconciliation of the singular with the general." Gilles Deleuze, Difference and Repetition, trans. by P. Patton, (New York: Columbia University Press, 1994), 25.

${ }^{4}$ To be clear: this text is not an exegetic work on Kierkegaard. Deleuze only refers to Fear and Trembling, Repetition and some passages from the Papirer, a mere part of Kierkegaard's oeuvre. I will ignore the question of whether Deleuze's reading of Kierkegaard is adequate, focusing instead on how Deleuze transforms Kierkegaard to fit his own problems. For a Kierkegaardian response to Deleuze's reading, see Clar's text from 1975.

${ }^{5}$ For example, see James Williams, Gilles Deleuze's Logic of Sense - A Critical Introduction and Guide (Edinburgh: Edinburgh University Press, 2008).

${ }^{6}$ Deleuze's Nietzschean side has always emphasized activity (see his frequent references to Nietzsche and "dancing" in Difference and Repetition). Adding a Kierkegaardian element to the mix, so to say, would then create a nice balance of two "passive" or contemplative aspects and two "active" aspects to Deleuzian ethics.

${ }^{7}$ Gilles Deleuze, Two Regimes of Madness - Texts and Interviews 1975-1995, trans. by A. Hodges and M. Taormina (Cambridge, MA: Semiotext(e) / MIT Press, 2007), 384.

${ }^{8}$ Gilles Deleuze, The logic of sense, trans. by M. Lester (London: Athlone Press, 1990), 102-103.

(c) 2014 Arjen Kleinherenbrink http://www.kritike.org/journal/issue 15/kleinherenbrink december2014.pdf ISSN 1908-7330 
is where Kierkegaard comes in. ${ }^{9}$ Deleuze's discussions on $a$ life and the associated neologisms just mentioned are permeated with references to and use of Kierkegaard's Fear and Trembling and Repetition, and it is with a detour through these texts that we can uncover Deleuze's intentions. ${ }^{10}$

\section{Life as a knight of faith}

Fear and Trembling and Repetition famously address the problem of how to become an authentic self. According to Kierkegaard this is a matter of purging our motives for acting of all contingency and temporal displacement. Only a relation of each present to an absolute can serve as sufficient ground to grant authenticity to our existence. Kierkegaard identifies four contingent modes of acting that must be avoided if such a relation with the absolute is to be attained. ${ }^{11}$

The first is recollection. To act out of recollection means to long for the restoration of a contingent past, so that the present will always fall short and disappoint. Recollection is a "discarded garment that does not fit,"12 a mode of living that stops life dead in its tracks by "an undoing of movement and a reversal of [life's] course, a trying to get back to the point prior to movement."13 The second is hope. To hope means to act on an envisioned

\footnotetext{
${ }_{9}^{9}$ Søren Kierkegaard, Fear and Trembling and Repetition, trans. and ed. by H.V. Hong and E.H. Hong (New Jersey: Princeton University Press, 1983). [Fear and Trembling will be subsequently cited as FT, while Repetition as $R$, followed by section then page number]

10 To give two examples: “... what does becoming-imperceptible signify? [ ... ] Becoming-imperceptible means many things. What is the relation between the (anorganic) imperceptible, the (asignifying) indiscernible, and the (asubjective) impersonal? A first response would be: to be like everybody else. That is what Kierkegaard relates in his story about the "knight of the faith," the man of becoming: to look at him, one would notice nothing, a bourgeois, nothing but a bourgeois [ ... ]: after a real rupture, one succeeds in being just like everybody else." Gilles Deleuze and Félix Guattari, A Thousand Plateaus - Capitalism and Schizophrenia 2, trans. by B. Massumi (Minneapolis: University of Minnesota Press, 1987), 279; “become like everyone, but in fact you have turned the "everyone" into a becoming. You have become imperceptible, clandestine [ ... ]. Despite the different tones, it is a little like the way in which Kierkegaard describes the knight of faith [ ... ]: the knight no longer has segments of resignation $[\ldots]$, he resembles rather a bourgeois, a tax collector, $[. .$.$] he blends into the wall but the wall has become$ alive, he is painted grey on grey." Gilles Deleuze and Claire Parnet, Dialogues, trans. by H. Tomlinson and B. Habberjam (New York: Columbia University Press, 1987), 127. Also see A Thousand Plateaus, 171, 197, 282, 543 n.66 and Gilles Deleuze and Félix Guattari, What is Philosophy?, trans. by H. Tomlinson and G. Burchell (New York: Columbia University Press, 1994), 73-74.

${ }^{11}$ And not just two, as is often thought. For Kierkegaard, "Hope" and "Recollection" are just as problematic as "Aesthetic" and "Ethic" existence.

${ }^{12} \mathrm{R}$ III, 174.

${ }^{13}$ John D. Caputo, "Kierkegaard, Heidegger, and the Foundering of Metaphysics," in R. L. Perkins ed., International Kierkegaard Commentary - Fear and Trembling and Repetition (Macon: Mercer University Press, 1993), 208.
}

(c) 2014 Arjen Kleinherenbrink

http://www.kritike.org/journal/issue 15/kleinherenbrink december2014.pdf

ISSN 1908-7330

(cc) BY-NC 
future that may never become reality. Whereas recollection is too "backward" to live up to the present, hope is too "forward." The third contingent mode is the aesthetic mode of existence, or to justify actions in terms of desires and sentiments one just happens to have. ${ }^{14}$ It refers to acts in which we pay no mind to others, a foreclosure from the public sphere, which leads Kierkegaard to call this mode "hidden." The fourth is the ethical mode, which Kierkegaard calls "disclosed" and "universal." It is to act in accordance with the normative framework of a society, rendering actions intelligible to all in principle. The ethical mode still cannot yield authentic selfhood, as it never grants certainty as to whether we are not just acting in order to be appreciated by others, which would reduce a person to a "limb of a larger body." 15 Kierkegaard gives the example of Agamemnon's intended sacrifice of his daughter to ensure favorable winds for the Greek fleet heading for Troy. ${ }^{16}$ Even though Agamemnon concedes his private interests to the universal, this cannot make him an authentic self. He remains driven by the need to conform to societal values that pertain to a contingent Greek universe.

These four modes can of course inspire noble and beautiful actions, yet they risk the surrender of one's life. Aesthetically, to worldly distractions; ethically, to social conformity; in recollection, to dreams of a past; in hope, to longing for a future. Instead of hoping or recollecting, Kierkegaard insists that we repeat: "he who will merely hope is cowardly; he who will merely recollect is voluptuous; he who wills repetition is a man, and the more emphatically he is able to realize it, the more profound a human being he is." 17 Instead of acting aesthetically or ethically, he insists on a religious mode of existence, the only one in which one can be a "single individual."18 This single individual is the knight of faith, certain of authentic selfhood precisely because he abandons all contingency in favor of "an absolute relation with the absolute." 19 Who is this knight of faith who repeats, and how is the relation with the absolute attained? To answer these questions, Kierkegaard famously employs the example of Abraham.

14 This makes for "slaves of the finite" are "frogs in the swamp of life" and "benchwarmers that live absorbed in worldly joys (FT III, 91-92), stuck in an "aesthetic illusion" (FT III, 135) of disdainful “bourgeois philistinism” (FT III, 89).

15 David Gouwens, “Understanding, imagination, and irony in Kierkegaard's Repetition," in International Kierkegaard Commentary - Fear and Trembling and Repetition, 14. Also see "no one becomes an authentic self simply by absorbing the values of one's society." Stephen Evans, "Faith as the telos of morality: a reading of Fear and trembling," in ibid., 25; it is "unacceptable to make a goal of being approved by other people" Morris, T. F., "Constantin Constantius" search for an acceptable way of life," in ibid., 333.

${ }^{16}$ FT III, 108.

${ }^{17} \mathrm{R}$ III, 174.

18 FT III, 105, 111, 124.

${ }^{19}$ FT III, 106. Note that Kierkegaard thus counterintuitively aligns universality with contingency, and opposes them to absoluteness and necessity.

(c) 2014 Arjen Kleinherenbrink http://www.kritike.org/journal/issue 15/kleinherenbrink december2014.pdf ISSN 1908-7330 
As is written, God commands Abraham to sacrifice his son Isaac. According to Kierkegaard, Abraham transcends the aesthetic and the ethical by obeying God without hesitation. He does not perform the sacrifice for his own sake (aesthetics) or for the benefit of his family (ethics). ${ }^{20}$ This is further confirmed by Abraham's concealment of his intentions to his loved ones. An aesthetic silence would have been intended to prevent the slaying by pretending that nothing had happened, not to help bring it about. ${ }^{21}$ Ethically speaking silence is not even a possibility, because the ethical mode requires by definition that one justifies actions in terms of common sense. ${ }^{22}$ Abraham must act utterly alone since his intentions are in principle unintelligible for others: though religiously he is about to sacrifice, ethically he is about to commit murder. ${ }^{23}$ Yet this ambiguity does not yet make a knight of faith. Abraham only deserves this title insofar as he has the absurd faith that by abandoning everything he will regain what he resigns:

But to be able to lose one's understanding and along with it everything finite, for which it is the stockbroker, and then to win the very same finitude again by virtue of the absurd - this appalls me, but that does not make me say it is something inferior, since, on the contrary, it is the one and only marvel. ${ }^{24}$

The knight of faith makes a twofold movement: surrendering the finite and then seeing it restored by virtue of the absurd (God intervening at the very last moment to save Isaac). This second part is crucial. Had Abraham stopped after the first part (accepting the sacrifice of his son without absurdly believing that Isaac would be restored to him), then he would merely be a "knight of infinite resignation." Resignation still relies on an ethical understanding that there is something that, unpleasant as it may be, has to be done. ${ }^{25}$ However, by absurdly believing that surrendering the finite will still result in the restoration of the finite, Abraham moves beyond understanding and resignation. This "leap" is absurd and paradoxical and thought cannot penetrate it, not in the last place because it places a single individual higher than the universal. Thus, Abraham becomes an authentic self, a single individual living a present in an absolute relation with the absolute. When

20 "For Abraham the ethical had no higher expression than family life." FT III, 158.

${ }^{21}$ FT III, 158.

22 "Abraham [ ... ] cannot speak. As soon as I speak, I express the universal, and if I do

not do so, no one can understand me." FT III, 110.

${ }^{23}$ FT III, 61-64, 66-67, 73, 82, 120.

${ }^{24}$ FT III, 87.

${ }^{25}$ FT III, 97.

(c) 2014 Arjen Kleinherenbrink http://www.kritike.org/journal/issue 15/kleinherenbrink december2014.pdf

ISSN 1908-7330

(cc) BY-NC 
everything finite is restored to him after his leap of faith, he can be certain that he is neither driven by selfish gain, nor by societal norms. ${ }^{26}$ This is because he repeats, and we now understand that to repeat is to regain what one has surrendered earlier. Repetition allows for authenticity through the certainty that one is not a slave to aesthetics, ethics, recollection, or hope, that one cannot be reduced to a private individual or a social subject. ${ }^{27}$ Only in this mode of existence can existence be called "earnest" for Kierkegaard. ${ }^{28}$ This leaping into an earnest existence is the first of two themes Deleuze adopts from the Danish philosopher. ${ }^{29}$

The second is Kierkegaard's description of "how the knight of faith should be played." ${ }^{30}$ Kierkegaard emphasizes how utterly devoid of spectacle it would be to see a knight of faith. Indeed, we would exclaim: "Good Lord, is this the man, is this really the one-he looks just like a tax collector!" 31 Glory and public recognition befall knights of infinite resignation, not knights of faith. The former can be publically staged as paragons of virtue, and we cry for them in sympathy because their actions correspond to our values. ${ }^{32}$ And even though with every breath, the knight of faith "buys the opportune time at the highest price, for he does not do even the slightest thing except by virtue of the absurd," there is nothing spectacular in watching him do it. ${ }^{33}$ The very marvel of faith according to Kierkegaard is that its movement is a mode of existence in which all of life, including its most common and trivial aspects, is restored to a person who thereby becomes a self, having left behind all other modes of existence or attitudes to life that would have subjected him to past, future, social doxa, or private passion. Hence, a knight of faith exists "in such a way that [his] contrast to existence constantly expresses itself as the most beautiful and secure harmony with it," as "the only happy man, the heir to the finite." 34

${ }^{26}$ FT III, 106, 120.

27 "Only the religious movement remains as the true expression for repetition ... " $R$, 302, Pap. IV B112 n.d., 1843-1844; "repetition is transcendent, a religious movement by virtue of the absurd", R, 305, Pap. IV B112 n.d., 1843-1844.

${ }^{28} R$ III, 133. Nevertheless, ethics does not contradict faith by definition and faith does not always demand acting in violation of ethics. Kierkegaard merely asserts that faith is superior to ethics and irreducible to it, not that it annuls it.

${ }^{29}$ Deleuze and Guattari, A Thousand Plateaus, 127, 282; What is philosophy?, 74; Deleuze, Difference and repetition, 11, 95; Gilles Deleuze, Cinema 1 - The Movement Image, trans. by H. Tomlinson and B. Habberjam (London: Athlone Press, 1986), 114-116.

${ }^{30}$ Deleuze, Difference and Repetition, 9; Deleuze and Guattari, A Thousand Plateaus, 197, 279.

${ }^{31}$ FT III, 90.

32 FT III, 89, 110, 115.

${ }^{33}$ FT III, 91.

${ }^{34}$ FT III, 100.

(c) 2014 Arjen Kleinherenbrink http://www.kritike.org/journal/issue 15/kleinherenbrink december2014.pdf ISSN 1908-7330 
These two figures, a movement putting a single individual in relation to something absolute, and simultaneously retaining a completely normal presence in the world, deeply influence Deleuze in conceptualizing a preferable mode of existence. Simultaneously, his version of the problem of becoming a single individual, or, in his terminology, living $a$ life in the fourth person singular, still differs from Kierkegaard's. How could it be otherwise when Deleuze demands a strict atheism in life and philosophy? ${ }^{35}$

\section{Abraham becomes Cain}

As with Kierkegaard's disavowal of recollection, Deleuze asserts that "history today still designates only the set of conditions, however recent they may be, from which one turns away in order to become, that is to say, in order to create something new." 36 Where Kierkegaard dismisses the ethical and aesthetic modes of existence, Deleuze also demands "a determination purely of thinking and of thought that wrests [existential modes] from the historical state of affairs of a society and the lived experience of individuals" in a "struggle against opinion." 37 And in a striking parallel with the knight of faith whose absurd faith cannot be adequately spoken of, Deleuze asserts that the most admirable mode of existence is one that cannot be judged: "better to be a road-sweeper than a judge";

... herein, perhaps, lies the secret: to bring into existence and not to judge. If it is so disgusting to judge, it is not because everything is of equal value, but on the contrary because what has value can be made or distinguished only by defying judgment. ${ }^{38}$

With such similarities, it is not surprising that Kierkegaard's knight of faith is Deleuze's primary association when inquiring into the preferable mode of existence. ${ }^{39}$ Yet this first response is no satisfying answer. Deleuze

35 "Atheism is the philosopher's serenity and philosophy's achievement." Deleuze and Guattari, What is Philosophy?, 92; "Pluralism is the properly philosophical way of thinking, the one principle of a violent atheism." Gilles Deleuze, Nietzsche and philosophy, trans. by H. Tomlinson (New York: Columbia University Press, 2006), 4; "Religions are worth much less than the nobility and the courage of the atheisms which they inspire." Deleuze, Two Regimes of Madness, 360.

${ }^{36}$ Deleuze and Guattari, What is Philosophy?, 96.

${ }^{37}$ Ibid., 70, 203.

${ }^{38}$ Deleuze and Parnet, Dialogues, 8; Shunning judgment by others and rejoicing in meeting someone who does not judge are also key themes in Repetition. See Morris' "Constantin Constantius" search for an acceptable way of life," especially pages 321-324: "Here was an actuality that was not concerned with judging him ...."

${ }^{39}$ Deleuze and Guattari, A Thousand Plateaus, 279.

(c) 2014 Arjen Kleinherenbrink

http://www.kritike.org/journal/issue 15/kleinherenbrink december2014.pdf

ISSN 1908-7330

(cc) $\mathrm{BY}-\mathrm{NC}$ 
agrees with Kierkegaard on which modes must be avoided, but cannot accept a religious movement of faith as a solution:

Undoubtedly, faith possesses sufficient force to undo habit and reminiscence [ ... ] However, faith invites us to rediscover once and for all God and the self in common resurrection. [ ... ] This is [Kierkegaard's] problem: the betrothal of a self rediscovered and a God recovered, in such a manner that it is no longer possible truly to escape from either the condition or the agent. ${ }^{40}$

By relying on God to restore the finite, the knight of faith is immediately propelled back into the very conditions of private habit and social mores that he needed to flee in the first place. For Kierkegaard, this is the beauty of absurd faith. For Deleuze, it is a disappointment: one escapes, only to rediscover oneself bound to the finite tighter than ever before. ${ }^{41}$ Yet Deleuze does not intend to critique Kierkegaard as much as he wants to point out that Kierkegaard's solution falls short in Deleuze's own version of Kierkegaard's problem:

Kierkegaard's "knight of the faith," he who makes the leap, are men [sic] of a transcendence or a faith. But they constantly recharge immanence $[\ldots]$, with the infinite immanent possibilities brought by the one who believes that God exists. The problem would change if it were another plane of immanence. It is not that the person who does not believe God exists would gain the upper hand $[\ldots]$. But, on the new plane, it is possible that the problem now concerns the one who believes in the world, and not even in the existence of the world but in its possibilities of movements and intensities, so as once again to give birth to new modes of existence [ ... ]. It may be that believing in this world, in this life, becomes our most difficult task [ ... ]. The problem has indeed changed. ${ }^{42}$

${ }^{40}$ Deleuze, Difference and Repetition, 95.

41 Kierkegaard aims for a new ground and a "God-relationship restored (and enhanced) by the incarnation and atonement of the Son of God." Vincent McCarthy, "Repetition's repetitions," in International Kierkegaard commentary - Fear and Trembling and Repetition, 277.

${ }^{42}$ Deleuze and Guattari, What is Philosophy?, 74-75.

(c) 2014 Arjen Kleinherenbrink http://www.kritike.org/journal/issue 15/kleinherenbrink december2014.pdf ISSN 1908-7330 
Deleuze shifts the parameters of the problem. It now concerns the belief in possibilities of movement and new modes of existence in the world. Authenticity is then no longer a matter of restoration, but of creation. The knight of faith chooses one final mode of existence. Deleuze searches something that escapes from private life, social conditions, recollection, and hope in a more radical sense: something that can continuously generate something unseen, not to restore the finite but to renew it. The obstacle to such renewal is precisely transcendence. In everyday life, this can be religious or cultural dogma that one is not supposed to question. In philosophy, it is the idea of a ground or first principle. Transcendence ensures that all events and things are watered down to mere permutations or reconfigurations of something already known and established for all eternity.

Quite obviously, Deleuze counts the religious mode of existence among such transcendent structures, and so the problem has changed. Becoming an authentic self still requires dismissing personal desire, social circumstance, and idealized pasts or futures, but religion has been added to this list and all these modes of existence are discounted for being contaminated with transcendence and opinion, which limit existence and attempt to capture life in clear-cut schemas. The ideal can no longer be the tranquil knight of faith; rather, we need a paragon of the creation of ruptures in the prisons of life. ${ }^{43}$ The shining example is no longer Abraham: Deleuze chooses Cain as his champion. Cain is "the true man" and a true man is one who "never ceases to betray God just as God betrays man." 44 God betrays man in representing transcendence par excellence. Absolute and not contingent as He may be, God still functions as a displacement of the justification of things from outside of themselves, i.e., as a position of judgment. Restoration of immanence or allowing for the new without pinning life to any limiting principle whatsoever demands that this betrayal be betrayed. Such double betrayal is the only way to break with "the doctrine of judgment [that] has reversed and replaced the system affects." 45 This provides us with the starting point of Deleuze's solution to his reading of Kierkegaard's problem. The preferable mode of existence breaks with all manifestations of stifling opinions and transcendent, untouchable principles, including faith. For Deleuze, this entails creating affects, in relation to which he introduces a complex series of neologisms.

\footnotetext{
${ }^{43}$ Ibid., 47.

${ }^{44}$ Deleuze and Guattari, A Thousand Plateaus, 123.

${ }^{45}$ Deleuze, Essays Critical and Clinical, 129.
} 


\section{Affect, sign, fourth person singular}

Affect is introduced to Deleuze's philosophy in two studies on Spinoza. However, in A Thousand Plateaus, Deleuze develops a markedly post-Spinozist conceptualization of affect. He starts using the term in response to a different problem: no longer Spinoza's "what can a body do?," but the problem mentioned earlier: the possibility of a world in which new modes of existence can emerge. ${ }^{46}$ Through this shift, affect becomes detached from the body: "affects are no longer feelings or affections," the flesh is now considered "too weak" to carry the affect, and affects are now "nonhuman becomings of man." 47 If affect is to play a part in breaking with the self and with opinion, it must be able to effectuate a power that "throws the self into upheaval and makes it reel." 48 It cannot concern a contingent person or body; affects must be "impersonal, an alternate current that disrupts signifying projects as well as subjective feelings." 49 What must affect be if it is to realize such ambitious aims? First of all it is a being and not a process of affection. ${ }^{50}$ When asked what type of being this entails, Deleuze answers "art," because only art can declare as its aim "to wrest the affect from affections as the transition from one state to another." 51 Affects are not simply encountered in nature; their creation is a complex techne, and for Deleuze, it is highly rare that a work of art truly creates an affect and manages to stand up on its own. ${ }^{52}$ To stand up on its own means that a work of art no longer refers to the lived experience of either artist or spectator, that it does not represent particular historical circumstances, that it neither recalls a past nor announces a future, and hence there is only an affect when the work of art refers to nothing but itself:

... the young girl maintains the pose that she has had for five thousand years, a gesture that no longer depends on whoever made it. ${ }^{33}$

${ }^{46}$ Deleuze and Guattari, A Thousand Plateaus, 256.

${ }^{47}$ Deleuze and Guattari, What is Philosophy?, 164, 178, 169/173.

${ }^{48}$ Deleuze and Guattari, A Thousand Plateaus, 240.

${ }^{49}$ Ibid., 233.

50 "Affects are beings." Deleuze and Guattari, What is philosophy?, 164.

${ }^{51}$ Ibid., 167.

${ }^{52}$ Ibid., 164. This is also how one should understand - "affects always presuppose the affections from which they are derived, although they cannot be reduced to them." Gilles Deleuze, Essays Critical and Clinical, trans. by D. W. Smith and M. E. Greco (Minneapolis: University of Minnesota Press, 1997), 140.

${ }^{53}$ Deleuze and Guattari, What is Philosophy?, 163.

(c) 2014 Arjen Kleinherenbrink http://www.kritike.org/journal/issue 15/kleinherenbrink december2014.pdf

ISSN 1908-7330 
This becomes Deleuze's hallmark of authenticity: not so much authenticity for the self, but authenticity by the self by virtue of that which is created. When successful, this drags the very materials from which the work of art is composed into the affect: "[even] the material passes into the sensation." 54 Sensations are not affections. A work of art "is a bloc of sensations, that is to say, a compound of percepts and affects." 55 Affects are thus never encountered alone, but always intertwined with percepts. Whereas affects are those entities that can generate affections, percepts are those entities that can generate perceptions. A work of art as an affect-percept compound is thus situated "before" language in the sense that it can come to be talked about after being perceived and felt:

$\ldots$ it is an utterable. We mean that, when language gets hold of this material (and it necessarily does so), then it gives rise to utterances which come to dominate or even replace the images and signs, and which refer in turn to pertinent features of the language system, syntagms and paradigms, completely different from those we started with. ${ }^{56}$

In addition, an affect-percept compound is eternal and thus absolute because "even if the material lasts for only a few seconds it will give sensation the power to exist and be preserved in itself in the eternity that coexists with this short duration." 57 The creation of affects is an activity of extraction, detachment, a cutting of ties with all modes of existence that must be dismissed on account of their capacity to enslave or imprison life in transcendence and opinion:

The painter does not paint on an empty canvas, and neither does the writer write on a blank page; but the page or canvas is already so covered with preexisting, preestablished clichés that it is first necessary to erase, to clean, to flatten, even to shred, so as to let in a breath of air from the chaos that brings us the vision [ ... ]. Because the picture starts out covered with clichés, the painter must confront the chaos and hasten the destruction as to

\footnotetext{
54 Ibid., 193.

${ }^{55}$ Ibid., 164.

${ }^{56}$ Deleuze, Gilles, Cinema 2 - The Time Image, trans. by H. Tomlinson and R. Galeta (Minneapolis: University of Minnesota Press, 1989), 29.

${ }^{57}$ Deleuze and Guattari, What is Philosophy?, 166.

(c) 2014 Arjen Kleinherenbrink http://www.kritike.org/journal/issue 15/kleinherenbrink december2014.pdf ISSN 1908-7330 
produce a sensation that defies every opinion and cliché. ${ }^{58}$

This helps to understand what Deleuze means when writing that affects respond to a necessity to break through opinion and cliché by "creating new, as yet unknown statements [ ... ], asubjective affects, signs without signifiance." ${ }^{59}$ Affects are asignifying signs because they do not refer to or represent something outside of themselves. If a painter manages to create an affect, a woman's smile on a painting no longer has "Lisa's smile," nor a "typical $16^{\text {th }}$ century expression," not even a smile consisting of this or that specific type of reddish paint. This is not to say that an affect cannot signify something; it is to say that an affect does not do so necessarily, and that when it does, it is only in a second moment. ${ }^{60}$ If it does not escape immediate signification, it remains firmly stuck in the known, in clichés, recognition, and opinion. This also explains Deleuze's resistance to judgment because what else is judgment than to capture something in terms and criteria belonging to something else? In the case of affect, this would annul everything it can be. A successful affect is an asignifying sign, a double betrayal that moves against or simply ignores what is already known and accepted, and thus "no [true] art and no sensation have ever been representational." 61 If an affect is to be judged, this must happen in terms of the affect itself, if such a thing is possible. The power of art lies in the possibility of the creation of affects and the power of affects lies in being relationally undetermined and hence allowing for the new. From the perspective of affect, any way of talking about, characterizing, or interpreting a work of art is just one way, and even a multitude of ways can in principle never exhaust the asignifying status of the affect. The introduction of affects and asignifying signs already provides a sense of what Deleuze is working towards. We are now in a position to return to the single individual or the fourth person singular:

58 Ibid., 204. Also: "everything that novelists must extract from the perceptions, affections, and opinions of their psychosocial "models" passes entirely into the percepts and affects to which the character must be raised without holding on to any other life." Ibid., 188.

${ }^{59}$ Deleuze and Guattari, A Thousand Plateaus, 147.

60 "[Art] is no less independent of the viewer or hearer, who only experience it after, if they have the strength for It." Deleuze and Guattari, What is Philosophy?, 164.

${ }^{61}$ Ibid., 193. Also "... we attain to the percept and affect only as to autonomous and sufficient beings that no longer owe anything to those who experience or have experienced them." Ibid., 168; "signs [ ... ] are not signifiers." Deleuze and Guattari, A Thousand Plateaus, 8889.

(c) 2014 Arjen Kleinherenbrink http://www.kritike.org/journal/issue 15/kleinherenbrink december2014.pdf ISSN 1908-7330 
We will say of pure immanence that it is A LIFE, and nothing more. ${ }^{62}$

In leaving behind all enslaving, stifling modes of existence, affect becomes completely singular. It is no longer this or that smile, but simply "a smile." Deleuze borrows the notion of the fourth person singular from the poet Lawrence Ferlinghetti. In the latter's novel Her, the protagonist Andy Raffine is obsessed with reaching the fourth person singular. He spends life searching for something absolute instead of relative, for $a$ girl exempt from the small flaws of real women. Of course, he never finds a girl, but why? It is because Andy longs for a thing so pure that he becomes unable to see himself "as a component in the viewing process." 63 Andy's search is doomed from the start, precisely because he has the wrong understanding of the fourth person singular: he looks for $a$ girl, but still one as conceived of from his perspective. However, Her also contains what Ferlinghetti calls the true fourth person singular, the "a ..." that manages to detach itself from the longings and desires of a subject. ${ }^{64}$ Ferlinghetti stages the true fourth person singular as the one mode of existence in which disappointment and lack become impossible: there is just the presence of a smile. The young girl whose smile it is and the spectator moved or unmoved by it are only relevant in a secondary sense. Quite understandably, this is an incredibly hard thing to achieve: "I keep slipping off [ ... ] because I and no one has the true fourth sight to see without the old associational turning eye that turns all it sees into its own." 65

Nevertheless, this is Deleuze's criterion for authenticity: to leave behind all modes of existence that are unable to generate the new. Again, Deleuze is approaching Kierkegaard's problem though in ways that Kierkegaard did not. It is no longer a search for a restoration of the Self; it is to search for moments of creation beyond the confines of the Self, until there is only "the it or the non-person," "hardly any individuality, but [ ... ] singularities, a smile, a gesture, a grimace-such events are not subjective traits," and hence where affect is created, there is only " $a$ belly, a mouth, an engine, $a$ thingamabob, $a$ baby." 66 Reaching the point of the indefinite article can reduce us to the point where everything we say and think about ourselves

\footnotetext{
${ }^{62}$ Deleuze, Two Regimes of Madness, 385.

${ }^{63}$ Lawrence Ianni and Lawrence Ferlinghetti, "Lawrence Ferlinghetti's Fourth Person Singular and the Theory of Relativity," in Winsconsin Studies in Contemporary Literature, 8:3 (1967), 396.

${ }^{64}$ Ferlinghetti, Lawrence, Her (New York: New Directions, 1988), 93; Ianni and Lawrence, "Lawrence Ferlinghetti's Fourth Person Singular and the Theory of Relativity," 400401.

${ }^{65}$ Ferlinghetti, Her, 93.

${ }^{66}$ Deleuze, Two Regimes of Madness, 351, 387, 110.

(c) 2014 Arjen Kleinherenbrink http://www.kritike.org/journal/issue 15/kleinherenbrink december2014.pdf ISSN 1908-7330 
is discarded, if only for a moment "one has combined "everything" (le tout): the indefinite article, the infinitive-becoming, and the proper name to which one is reduced." 67 This is why Deleuze often remarks that affect operates at infinite speed. Not only is art eternal as long as it lasts, it is also something detached from the rhythms of everyday life. This clarifies why Deleuze finds that so many novels fail to be art, that is, to create affects: too much ink is being wasted on recounting private affairs, and too little of it manages the desirable detachment, singularity, and reduction:

... the art of the novel [ ... ] is a misunderstanding: many people think that novels can be created with our perceptions and affections, our memories and archives, [ ... ] and finally with our opinions holding it all together. ${ }^{68}$

\section{Architecture, becoming, imperceptibility}

Deleuze cannot follow Kierkegaard, since the movement of faith entails transcendence reinstalled. He thus turns to Cain as the double betrayer. The activity by which to carry out such double betrayal and opening to the new is art because only art can create something purely for itself. Affects are beings: singular, asignifying signs that must be addressed in the fourth person singular. And Deleuze does not stop there. As affect cannot depend on emotions, feelings, or bodily states, he concludes that "art begins not with flesh but with the house." 69 Art is always the activity by which something is detached, and such singularization is a matter of framing, of demarcating and hence decoupling by means of lines, gestures, windows, beams, glass, and so forth. The affect is not found; it must be built. Art is impossible otherwise and as such "architecture, the first of the arts." ${ }^{70}$ As a consequence, the design of buildings is only a subset of a wider architectural domain. For Deleuze, architecture concerns all art as the necessary condition for the creation of affect. Cinema is a good example here. Framing a face in close-up can show fear of resignation as affect. Because of the close-up, context drifts away, and as the face itself becomes a landscape that fills the entire screen, the actor's identity dissipates. All that remains is " $a$ " fear or "a" resignation in which the affect has been abstracted from all contingent circumstances. At that point, a

${ }^{67}$ Deleuze and Guattari, A Thousand Plateaus, 280.

${ }^{68}$ Deleuze and Guattari, What is Philosophy?, 170. Kierkegaard could not agree more, as he insists that an author should not draw too much on personal experience, lest his actuality intrude so much that a work becomes mere "private talkativeness." Fear and Trembling and Repetition, 98.

${ }^{69}$ Deleuze and Guattari, What is Philosophy?, 186, 189, italics mine.

${ }^{70} \mathrm{Ibid} ., 179$.

(c) 2014 Arjen Kleinherenbrink http://www.kritike.org/journal/issue 15/kleinherenbrink december2014.pdf ISSN 1908-7330 


\section{ART AS AUTHENTIC LIFE}

viewer has the rare opportunity to enter into a situation in which there is only the fourth person singular. The subject-object distinction is then momentarily denied and immanence is "recharged" by a moment of contact with something that does not belong to our quotidian experiences. But this is still art as a specific practice. How can art and affect be the general mode of existence par excellence? Deleuze's conceptualizations seem to concern very isolated moments that will only rarely be created and experienced. The next step in the sequence of concepts, however, suggests otherwise when Deleuze asserts that:

... you are $[\ldots]$ a set of nonsubjectified affects. You have the individuality of a day, a season, a year, a life. ${ }^{71}$

This can be understood by turning to a final concept, that of "becoming": "the house takes part in an entire becoming. It is life, the nonorganic life of things."72 Architecture is part of a movement of becoming, which reveals the nonorganic life of things. This refers to things taken as asignifying or in the fourth person singular. This is a constant theme in Deleuze's philosophy, where anything functioning within a certain structure or system is always doing so in a second moment, conditioned by something else. Hence, he writes that "real becomings take refuge in art and sweep it away toward the realms of the asignifying, asubjective, and faceless," and that "affects [are] becomings that spill over beyond whoever lives through them (thereby becoming someone else)."73 Becoming is a movement that belongs to raising compositions to affects, to the detachment and singularization mentioned earlier. What is becoming in this context of sensational compounds of affect and percept? Deleuze answers:

... sensory becoming is the action by which something or someone is ceaselessly becoming-other while continuing to be what they are. ${ }^{74}$

How to reconcile becoming-other with continuing to be what one is? Becoming is a movement similar to repetition or the movement of faith in Kierkegaard: one constantly abandons oneself in favor of something else, but this very act allows one to remain oneself. Deleuze intends that the mode of existence preferable for human beings is this becoming-other, as the essence of selfhood becomes becoming-other: "here begins a long and inexhaustible

\footnotetext{
${ }^{71}$ Deleuze and Guattari, A Thousand Plateaus, 262.

72 Deleuze and Guattari, What is Philosophy?, 180.

${ }^{73}$ Deleuze and Guattari, A Thousand Plateaus, 208.

${ }^{74}$ Deleuze and Guattari, What is Philosophy?, 177.
} 
story: I is an other, or the paradox of inner sense."75 After private individuality, social context, and all transcendent illusions and limiting grounds are left behind, the only thing remaining is movement itself. With Kierkegaard's knight, this is always done towards and from faith. For him, it is raising consciousness "to the second power," but for Deleuze it is a more radical raising of consciousness to what he calls the "nth power," the double betrayal of Cain that unshackles us for the sake of allowing for the new. ${ }^{76}$

As with Kierkegaard, this requires no spectacle, since "movement is the thing that is imperceptible."77 The mode of existence of being a set of nonsubjectified affects entails a radical transformation from the perspective of the life of doxa that Deleuze considers to be the norm, but this transformation is not physical. Throughout A Thousand Plateaus, the many examples of becomings (becoming-woman, becoming-animal, and so on) are always accompanied by the reminder that a man becoming-woman or a child becoming-horse does not actually become something else in a direct, literal sense. Hence, becoming a set of asubjectified affects can only concern a movement on the spot, in other words, a certain attitude or approach to life, or again in other words, a preference for a specific mode of existence: an attitude. As with Ferlinghetti's true fourth person singular, maintaining this mode of existence is hard, and one might only succeed in it for a fleeting moment:

To go unnoticed is by no means easy. To be a stranger, even to one's doorman or neighbors. If it is so difficult to be "like" everybody else, it is because it is an affair of becoming. Not everybody becomes everybody/everything [tout le monde], makes a becoming of everybody/everything. This requires much asceticism, much sobriety, much creative involution. ${ }^{78}$

To become tout le monde is to abandon oneself in the precise sense of realizing situations in which there is no longer a subject-object distinction, in which a morsel of reality is present as "a smile," not this or that smile that I am interpreting. Since this is a movement on the spot, it is like "painting grey on grey" or "pink on pink": it might not change anything physically, yet simultaneously it matters tremendously in how one relates to the world. ${ }^{79}$

${ }^{75}$ Deleuze, Difference and Repetition, 86.

${ }^{76}$ Pap. IV B111 n.d., 1843-1844; $R$ III, 229. Deleuze most notably employs the term "nth power" throughout Difference and Repetition.

77 Deleuze and Guattari, A Thousand Plateaus, 280.

${ }^{78}$ Ibid., 279.

${ }^{79}$ Deleuze and Guattari, A Thousand Plateaus, 11, 197.

(c) 2014 Arjen Kleinherenbrink http://www.kritike.org/journal/issue 15/kleinherenbrink december2014.pdf ISSN 1908-7330 


\section{ART AS AUTHENTIC LIFE}

This reveals two reasons why Deleuze describes true becoming as becomingimperceptible. Firstly, it is not visible "from the outside." Secondly, becoming puts us in a zone of indiscernibility, in situations in which there is "a ..." taking place, and therefore in which it is not at all clear where "I" stop and "it" starts. ${ }^{80}$

At this point, it is clear why Deleuze considers this mode of existence as superior to all others. Firstly, it is the only mode in which an event or encounter is truly appreciated for what it is, as singular and as unmediated by memory, anticipation, norms, values, language, and so forth. It is an extremely strict criterion for authenticity, in which even the perspective or desire of the subject involved is purged. Secondly, it is the only attitude towards life in which something new can come into being. Only from the fourth person singular can one say that something, which is then to be taken as an affect, is not a mere reconfiguration of pre-existing components. Thirdly, and more generally, much of Deleuze's thought is dedicated to demonstrating that the self or subject is not given a priori, and concepts such as affect and becoming are part of his endeavor of describing a world of experiences and encounters that is more fundamental than our "normal" way of seeing things, a world that is in fact constitutive of this normality. Hence, for Deleuze, the preferable mode of existence, of being a self, is an attitude in which one tries to have encounters that put the self beyond the self, that make becoming-other as an always present yet mostly unnoticed constitutive process, tangible, if only for a moment.

\section{Conclusion}

How to look at a work of art? With a cynical, weary eye that can only see it as resembling other art, as when we utter the cliché that "everything has already been done a thousand times before"? If so, then there is no art, just images. For Deleuze, the same is true for living a life. We can easily live life as though everything derives from circumstance, from history, or from others. This is life devoid of authenticity. But if so, then there is no life worth living, or at least no possible future worth entering. To Deleuze, the Cainite mode of existence, the double betrayal that allows for singular encounters unshackled from circumstance, is our only chance of experiencing moments in which something new is created. ${ }^{81}$ And the experience of the new is preferable, precisely because it is the only experience that is not (yet) captured in orders of transcendence, whether common sense and opinion or the edifices and first principles of philosophy. It is the only mode of existence in

${ }^{80}$ This is how one should read "what cannot be perceived on one [level] cannot but be perceived on the other." Deleuze and Guattari, A Thousand Plateaus, 281.

${ }^{81}$ Deleuze and Guattari, What is Philosophy?, 97.

(c) 2014 Arjen Kleinherenbrink

http://www.kritike.org/journal/issue 15/kleinherenbrink december2014.pdf

ISSN 1908-7330

(cc) $\mathrm{B} Y-\mathrm{NC}$ 
which "immanence can be restored", resulting in "Man par excellence." But this is precisely Man capable of severing his own involvement from the mode of existence of that which is produced, i.e., art. It must be emphasized that such moments cannot be forced: an individual subject cannot go out and "decide" to have an encounter with the new. Instead, one can only experiment and try to seek it out: "make consciousness an experimentation in life." 82 If this does not strike us as a very practical or concrete rule by which to live, it is only because it is first and foremost an encouragement to cultivate a certain attitude. The entire emphasis on viewing ourselves and others as art, on viewing art $a$ s affect, and on understanding affect as an utterable or perceivable is intended for this: an attitude in life in which we refuse to first see a problem, a situation, a person, or any other concrete thing in terms of that which it is not. This is why Deleuze so frequently cries out against stereotypes and popular opinion, and also why his philosophy has always resonated well with those who resist racism, sexism, and all other forms of essentialism in both theory and practice. At the heart of Deleuze's ethics is the attempt to see things in terms of themselves as much as possible. Not that this is guaranteed to make the world a better place, but at the very least it might make it more authentic.

Deleuze calls this "choosing to have a choice" in which "the alternative is not between terms but between the modes of existence of the one who chooses," for which he credits Pascal's Wager and Kierkegaard's Either/Or as the first texts to develop this insight. ${ }^{83}$ The true choice is not to have $a$ life or to create affects, especially not since such matters are highly asubjective. The self, strictly speaking, does not have the capacity to realize the proper mode of existence, much like the knight of faith cannot exist without God restoring the finite for him. The true choice is to believe that $a$ life and affect are possible in this world. Only "the character who makes [this] true choice raises the affect to its pure power or potentiality." 84 In his final essay, Deleuze cites a Dickens story that perhaps illustrates best how the affect-creating potential of art can become manifest in life itself:

A scoundrel, a bad apple, held in contempt by everyone, is found on the point of death, and suddenly those charged with his care display an urgency, respect, and even love for the dying man's least sign of life. Everyone

82 Deleuze and Guattari, A Thousand Plateaus, 134. Also see Deleuze and Parnet, Dialogues, 61. In a striking parallel, it was Kierkegaard who introduced the word experiment into Danish, as well as the explicit notion of experimenting not experimenting with or on, but a character. See pages xxii-xxxi of the 1993 International Kierkegaard Commentary.

${ }^{83}$ Deleuze, Cinema 1, 114-116; Deleuze, Cinema 2, 177.

${ }^{84}$ Deleuze, Cinema 1, 115.

(C) 2014 Arjen Kleinherenbrink http://www.kritike.org/journal/issue 15/kleinherenbrink december2014.pdf

ISSN 1908-7330 
makes it his business to save him. As a result, the wicked man himself, in the depths of his coma, feels something soft and sweet penetrate his soul. But as he progresses back toward life, his benefactors turn cold, and he himself rediscovers his old vulgarity and meanness. Between his life and his death, there is a moment where a life is merely playing with death. ${ }^{85}$

This demonstrates why the preferable mode of existence, a moment in which the fourth person singular is attained, is strictly speaking beyond good and evil, since "only the subject that incarnated [a life] in the midst of things made it good or bad." 86 And this is why Deleuzian ethics are perhaps existentialist before being anything else. Authenticity resides in the demand that the value of an act, of a production of something, can never be drawn from a cherished history, an envisioned future, a desire felt, or a norm obeyed. To be authentic is to even purge one's own presence from the affect under consideration, and to evaluate only it in terms of the feelings, perceptions and consequences that it might bring about. And finally, unlike the knight of faith, this can no longer concern every waking moment. Much more, it is the kind of rare occurrence that demands sobriety, work, and the kind of restricted optimism of one who merely labors to bring about something new, as humble as the result may be.

Center for Contemporary European Philosophy, Radboud University Nijmegen, the Netherlands

\section{References}

Boundas, Constantin V., "Foreclosure of the Other: from Sartre to Deleuze," in Journal of the British society for phenomenology, 24:1 (1993), 32-43.

Caputo, John D., "Kierkegaard, Heidegger, and the Foundering of Metaphysics," in R. L. Perkins ed., International Kierkegaard commentary - Fear and trembling and Repetition (Macon: Mercer University Press, 1993).

Clar, André, "Médiation et Répétition: le lieu de la dialectique Kierkegaardienne," in Revue des sciences philosophiques et théologiques, 59:1 (1975), 38-78.

Deleuze, Gilles, Cinema 1 - The Movement Image, trans. by H. Tomlinson and B. Habberjam (London: Athlone Press, 1986).

${ }^{85}$ Deleuze, Two Regimes of Madness, 386.

${ }^{86}$ Ibid., 387.

(c) 2014 Arjen Kleinherenbrink http://www.kritike.org/journal/issue 15/kleinherenbrink december2014.pdf

ISSN 1908-7330

(cc) $\mathrm{B} Y-\mathrm{NC}$ 
Cinema 2 - The Time Image, trans. By H. Tomlinson and R. Galeta (Minneapolis: University of Minnesota Press, 1989). 1990). The Logic of Sense, trans. by M. Lester (London: Athlone Press,

Difference and Repetition, trans. by P. Patton (New York: Columbia University Press, 1994). Essays Critical and Clinical, trans. by D. W. Smith and M. E. Greco (Minneapolis: University of Minnesota Press, 1997). Nietzsche and Philosophy, trans. by H. Tomlinson (New York: Columbia University Press, 2006). Two Regimes of Madness - Texts and Interviews 1975-1995, trans. by A. Hodges and M. Taormina (Cambridge, MA: Semiotext(e) / MIT Press, 2007).

Deleuze, Gilles and Parnet, Claire, Dialogues, trans. by H. Tomlinson and B. Habberjam (New York: Columbia University Press, 1987).

Deleuze, Gilles and Guattari, Félix, A Thousand Plateaus - Capitalism and Schizophrenia 2, trans. by B. Massumi (Minneapolis: University of Minnesota Press, 1987).

What is Philosophy?, trans. by H. Tomlinson and G. Burchell (New York: Columbia University Press, 1994).

Dosse, François, Gilles Deleuze and Félix Guattari - Intersecting Lives (New York: Columbia University Press, 2010).

Evans, Stephen, "Faith as the Telos of Morality: A Reading of Fear and Trembling," in R. L. Perkins ed., International Kierkegaard Commentary - Fear and trembling and Repetition (Macon: Mercer University Press, 1993).

Ferlinghetti, Lawrence, Her (New York: New Directions, 1988).

Gouwens, David, "Understanding, Imagination, and Irony in Kierkegaard's Repetition," in R. L. Perkins ed., International Kierkegaard Commentary - Fear and trembling and Repetition (Macon: Mercer University Press, 1993).

Ianni, Lawrence and Ferlinghetti, Lawrence, "Lawrence Ferlinghetti's Fourth Person Singular and the Theory of Relativity," in Winsconsin Studies in Contemporary Literature, 8:3 (1967), 392-406.

Khalfa, Jean, "Deleuze et Sartre: idée d'une conscience impersonelle," in Les temps modernes, 55:608 (2000), 189-222.

Kierkegaard, Søren, Fear and Trembling and Repetition, trans. and ed. by H.V. Hong and E.H. Hong (New Jersey: Princeton University Press, 1983). McCarthy, Vincent, "Repetition's repetitions," in R. L. Perkins ed., International Kierkegaard Commentary - Fear and trembling and Repetition (Macon: Mercer University Press, 1993).

(c) 2014 Arjen Kleinherenbrink http://www.kritike.org/journal/issue 15/kleinherenbrink december2014.pdf ISSN 1908-7330 


\section{ART AS AUTHENTIC LIFE}

Morris, T. F., "Constantin Constantius" search for an acceptable way of life," in R. L. Perkins ed., International Kierkegaard Commentary - Fear and trembling and Repetition (Macon: Mercer University Press, 1993).

Somers-Hall, Henry, "Sartre and the virtual - a Deleuzian Interpretation of the Transcendence of the Ego," in Philosophy Today (SPEP supplement), 50:5 (2006), 126-132.

Williams, James, Gilles Deleuze's Logic of Sense - A Critical Introduction and Guide (Edinburgh: Edinburgh University Press, 2008). 